\title{
Pengembangan Potensi Joglo dan Gamelan sebagai Tujuan Wisata Budaya
}

\author{
Rela Adi Himarosa ${ }^{1}$, Cahyo Setiadi Ramadhan², Evy Yulianti ${ }^{3}$ \\ 1, 2 Universitas Muhammadiyah Yogyakarta, ${ }^{3}$ Universitas Negeri Yogyakarta
}

\begin{abstract}
Article History ABSTRACT
Received 20.07.2019

Received in revised form 22.09.2019

Accepted 10.10.2019

Available online 28.10.2019

POTENTIAL EXPANSION OF JOGLO AND GAMELAN AS CULTURAL TOURISM DESTINATIONS. Joglo is one of the heritage forms of traditional Javanese houses in Yogyakarta, as well as traditional Gamelan musical instruments. The former Head of the Gilangharjo Village Jetis, Gilangharjo, Pandak, Bantul opened a Joglo with a set of Gamelan music equipment. Joglo has been approved as a cultural heritage building by the DIY Provincial Government. Even though Joglo has become a cultural heritage building, the potency for cultural heritage houses and Gamelan musical instruments are underutilized by residents. The development of Joglo cultural tourism and Gamelan will run well by involving the village community. This service aims to empower the community to increase the potency of Joglo and Gamelan to become cultural tourism destination and become community-based tourism. The purpose of this service are to participate by involving the village community involved in tourism development and starting to become known as the Joglo location and Gamelan arts in Jetis Village. The results of this service consist of profiles of Joglo websites and videos. Utilizing the advances in information technology and social media, the more popular Joglo in Jetis RT 03.
\end{abstract}

KEYWORDS: Gamelan, Heritage, Joglo, Tourism.

\section{PENDAHULUAN}

Desa Gilangharjo secara umum merupakan desa dengan tipologi persawahan. Adapun ada beberapa pedukuhan memang memiliki jenis tanah yang liat, namun secara umum masih produktif untuk pertanian dan berkebun. Jetis Desa Gilangharjo, Pandak, Bantul berjarak sekitar $15 \mathrm{~km}$ dari kampus UMY, dan $6 \mathrm{~km}$ dari pusat kota Bantul. Akses yang tidak terlalu jauh dari pusat kota Bantul tetapi kondisi di Jetis masih banyak warga yang memiliki taraf hidup rendah dan semakin banyak penduduk yang tidak memiliki pekerjaan tetap. Sumber pendapatan utama dari sektor pertanian, dan pengrajin kandang

${ }^{1}$ Corresponding author: Program Studi Teknik Mesin, Universitas Muhammadiyah Yogyakarta; Jl. Brawijaya, Geblagan, Tamantirto, Kec. Kasihan, Bantul, Daerah Istimewa Yogyakarta 55183; Email: rela.himarosa@umy.ac.id 
bambu. Penduduk wanita sebagian besar hanya sebagai ibu rumah tangga, atau sekedar membantu pekerjaan suami sebagai pengrajin kandang bambu.

Permasalahan sulitnya mencari lapangan kerja dikarenakan kurangnya kompetensi dan pendidikan hal tersebut menjadi penyebab utama rendahnya taraf hidup. Kampus sebagai agen perubahan berkewajiban berperan aktif melalui program Pengabdian Pengembangan Desa Mitra (PPDM) sebagai bentuk kepedulian kampus terhadap masyarakat di Jetis, Gilangharjo, Pandak, Bantul sebagai salah satu upaya memberikan ide-ide dan merangsang untuk menjadi masyarakat produktif. Kreatifitas yang ditularkan dari perguruan tinggi mampu menggali potensi-potensi yang ada disekitar sehingga mampu berdampak terhadap naiknya ekonomi masyarakat, produktifitas, dan taraf hidup.

Masyarakat warga RT 03 Jetis, Gilangharjo, Pandak, Bantul memiliki potensi yang belum dimanfaatkan dari keberadaan rumah Joglo dan alat musik Gamelan milik mantan kepala desa Gilangharjo. Rumah joglo salah satu perwujudan estetika tradisi Jawa. Desain dan rancangannya memiliki kedalaman makna, tersusun dari struktur bagian luar yang tampak, dan struktur bagian dalam yang tersembunyi, keduanya berkaitan satu sama lain. Relasi antar struktur rumah tradisional Jawa menggambarkan kedalaman makna. Makna desain rumah Jawa dijiwai dengan kultur setempat dan selalu dijunjung tinggi, sehingga dijadikan sebuah simbol dari kebudayaannya (Subiyantoro, 2011). Keberadaan rumah Joglo di Jetis, Gilangharjo, Pandak, Bantul merupakan potensi besar untuk menjadikan Joglo di desa tersebut sebagai tujuan wisata budaya. Wisata budaya dalam beberapa tahun terakhir mengalami kenaikan yang signifikan. Joglo dan Gamelan merupakan sebuah peninggalan (heritage) dalam konteks kepariwisataan adalah bagian penting dari wisata budaya (Widyawati, 2018).

Rendahnya tingkat pendidikan warga setempat sehingga profesi sebagai pengrajin kandang menjadi dominan di RT 03 Jetis, Gilangharjo. Seorang kepala keluarga dibantu istri dalam satu hari mampu memproduksi 1 kandang ayam yang dijual seharga 50-90 ribu rupiah. Selain sebagai pengrajin kandang warga juga bekerja sebagai buruh tani maupun buruh bangunan. Akibat rendahnya tingkat ekonomi menyebabkan masyarakat tidak ada kepedulian terhadap bangunan Joglo Cagar Budaya dan kesenian Gamelan yang memiliki potensi nilai budaya. Permasalahan desa tersebut adalah kurangnya inisiatif warga dan peran warga sebagai penggerak kreatifitas untuk mengembangkan dan memanfaatkan potensi yang ada, sehingga keberadaan rumah Joglo Cagar Budaya dan peralatan Gamelan di desa tersebut tidak dimanfaatkan secara optimal oleh masyarakat desa.

\section{METODE PELAKSANAAN}

Tahun 2018 Provinsi Daerah Istimewa Yogyakarta mendapatkan alokasi Dana Keistimewaan (Danais) sebesar Rp. 1 trilliun rupiah (Raharjo, 2017). Besarnya anggaran tersebut menunjukkan bahwa alokasi peningkatan kesejahteraan untuk desa cukup tinggi. Desain rumah Joglo sudah hampir tidak ada yang menggunakan sebagai bentuk rumah yang dibangun pada era ini. Selain membutuhkan luas lahan yang besar, konstruksi rumah Joglo yang terbuat dari kayu sudah sangat mahal dan tidak terjangkau oleh masyarakat. Kelangkaan rumah Joglo asli menjadikan rumah Joglo sebagai bentuk warisan budaya. 
Masyarakat warga Jetis RT 03, Gilangharjo, Pandak, Bantul memiliki potensi yang belum dimanfaatkan dari keberadaan rumah Joglo dan alat musik Gamelan milik mantan kepala desa Gilangharjo. Alat musik Gamelan merupakan alat musik tradisional dari Indonesia. Gamelan memiliki karaktersitik bunyi yang khas dari setiap daerah di Indonesia (Herington et al, 2010) Alat musik Gamelan sudah mulai ditinggalkan oleh generasi saat ini. Ironisnya banyak peneliti luar negeri meneliti tentang alat musik Gamelan. Profesor Sinin Hamdan yang berasal dari Malaysia salah satu peneliti tentang Gamelan. Profesor Sinin mengungkapkan bahwa di Malaysia sebuah kebanggan jika suatu Universitas memilik alat musik Gamelan.

Pengabdian ini berusaha mengajak masyarakat sebagai mitra untuk melestarikan warisan budaya. Rumah Joglo dan Gamelan berpotensi untuk dikelola sebagai obyek tujuan wisata budaya yang akan mampu mendatangkan banyak wisatawan, dengan begitu akan mendatangkan sumber pendapatan lain untuk warga setempat. Membenahi area Joglo dan Gamelan menjadi lokasi yang menarik dan membentuk sebuah tren mencintai warisan budaya sebagai daya tarik wisatawan. Memanfaatkan perkembangan teknologi, jaringan media sosial sebagai sarana untuk membangun tren budaya sebagai bentuk aktualisasi bergengsi. Joglo mampu dijadikan untuk tujuan belajar rumah budaya, konstruksi bangunan, dan lokasi foto yang menarik. Bagitu juga Gamelan mampu dikemas sebagai sarana edukasi musik tradisional untuk wisatawan bahkan fasilitas penelitian Gamelan.

Hasil dari pengabdian ini dapat diukur dengan kenaikan jumlah orang yang mengetahui informasi adanya Joglo budaya ini dan diharapkan akan mulai ke Joglo. Selain itu bentuk publikasi secara online tentang artikel yang berkaitan dengan Joglo maupun Gamelan dapat meningkatkan perhatian masyarakat luas yang diharapkan mampu berdampak terhadap kenaikan ekonomi warga setempat. Program pengembangan destinasi wisata di Daerah Istimewa Yogyakarta semakin digaungkan berdasarkan Visi yang telah dicanangkan oleh pimpinan dinas Pariwisata Daerah Instimewa Yogyakarta yaitu "Terwujudnya Yogyakarta pada tahun 2025 sebagai Destinasi Pariwisata berbasis budaya terkemuka di Asia Tenggara, berkelas dunia, berdaya saing, berkelanjutan, mampu mendorong pembangunan Daerah untuk kesejahteraan masyarakat" (Riyanta, 2018).

\section{HASIL DAN PEMBAHASAN}

Desa wisata didefinisikan sebagai bentuk integrasi antara atraksi, akomodasi, dan fasilitas pendukung yang disajikan dalam suatu struktur kehidupan masyarakat yang menyatu dengan tata cara tradisi yang berlaku (Priyanto dan Safitri, 2016). Pengelolaan pariwisata yang melibatkan masyarakat lokal dalam pengembangan dan pengelolaannya, sehingga dapat berkelanjutan dan mampu untuk meningkatkan ekonomi warga masyarakat (Sudarmadi, 2018). Langkah awal dengan edukasi warga bahwa pariwisata budaya memiliki potensi terbesar di Indonesia seperti dikutip pada portal online swa.co.id (Maulana, 2017). 


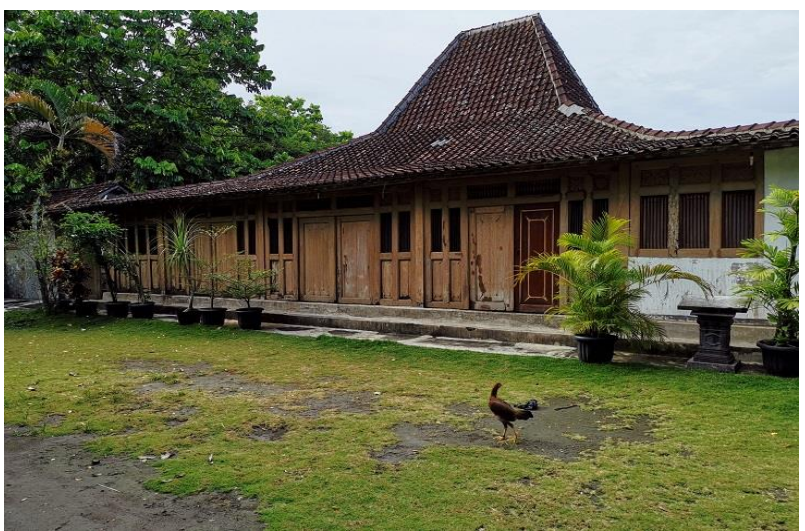

Gambar 1. Joglo dan Taman Halaman Depan

Pengembangan wisata budaya dimulai dengan melakukan beberapa renovasi Joglo dan Gamelan terutama perihal kebersihan dan penataan interior didalam Joglo. Membangun landscaping taman di halaman luar Joglo untuk menguatkan nuansa dan mempercantik lokasi. Langkah selanjutnya membuat profil dan edukasi tentang filosofi arsitektural Joglo dan musik Gamelan. Membuat area dalam Joglo menjadi tempat edukasi tentang sejarah perkembangan arsitektural Joglo, Gamelan, terhadap kemajuan peradaban masyarakat lalu dan perkembangan dakwah Islam secara kultural. Edukasi ini akan menarik warga sekolah sekitar untuk menambah wawasan dengan berwisata di lokasi tersebut. Joglo dan Gamelan dapat menjadi alternatif lokasi foto bertema budaya yang akan menarik bagi para penggemar selfie. Industri pariwista dan ditunjang fenomena selfie yang semakin marak. Fenomena selfie dan penggunaan media sosial sudah menjadi kebutuhan untuk menunjukkan aktualisasi diri dihadapan orang lain (Purwanti, 2015).

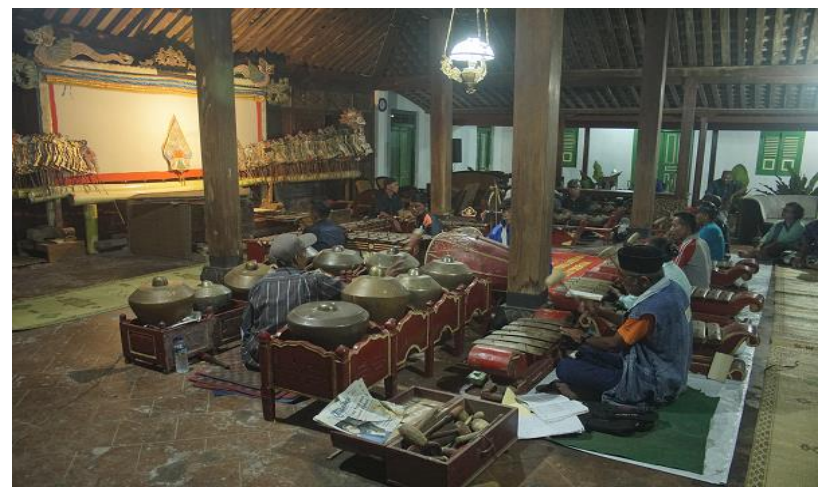

Gambar 2. Warga Menggunakan Pendopo untuk Berlatih Pagelaran Wayang

Hasil pengabdian kepada masyarakat yang berjudul Pengembangan Potensi Joglo dan Gamelan di Desa Jetis Gilangharjo Pandak Bantul sebagai tujuan Wisata Budaya ini yaitu sebuah peningkatan pemahaman masyarakat tentang potensi pariwisata budaya. Produk dari pengabian tersebut berupa website resmi Joglo sebagai tujuan utama wisata budaya. Website mampu menjadi pondasi untuk mengembangkan segala aktivitas budaya yang bisa dijadikan objek wisata. Joglo sudah dijadikan sebagai tempat kebudayaan dan pengabdian ini membuatkan sebuah wadah untuk mempromosikan ketrampilan dan potensi budaya yang ditampilkan seperti gamelan dan wayang, serta ketoprak. Website dibuat menggunakan wordpress.com sehingga mudah dalam 
pengelolaan untuk menambahkan konten aktivitas-aktivitas kebudayaan yang berlangsung di Joglo. Selain website dibuat video profil dengan mengambil aktivitas saat berlatih pagelaran wayang. Video tersebut diunggah melalui kanal YouTube sehingga mempermudah mempromosikan aktivitas dan keberadaan Joglo ini. Tampilan website ditunjukkan Gambar 3.

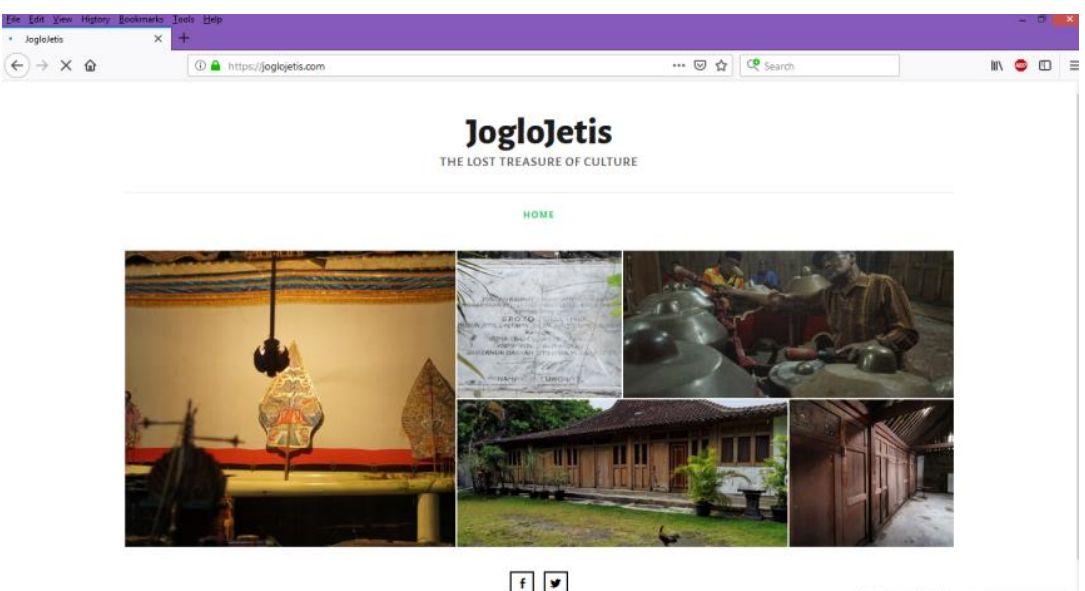

Gambar 3. Tampilan Website joglojetis.com

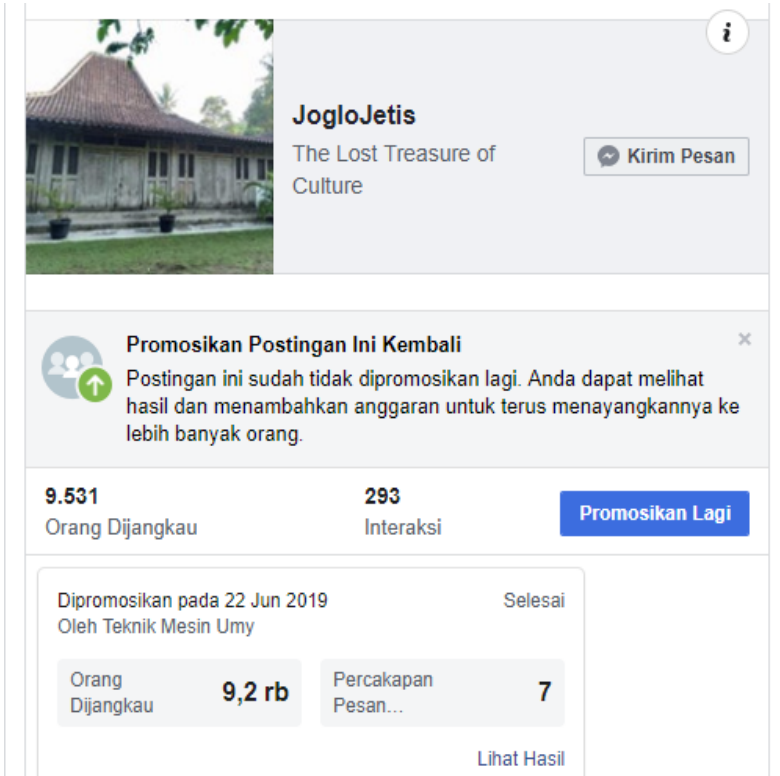

Gambar 4. Hasil promosi joglo menggunakan Facebook Advertising

Gambar 4 menunjukkan hasil promosi yang menggunakan fasilitas Facebook Advertising, dari data iklan ada 9.531 orang yang dijangkau diperlihatkan iklan JogloJetis, dan ada 293 interaksi yang terjadi terhadap konten dari iklan ini. Hal ini merupakan langkah awal cara mempromosikan Joglo, profil website merupakan pondasi awal dari media promosi yang dikembangkan di era informasi digital.

Pengembangan ini merupakan langkah awal untuk memicu kreativitas warga masyarakat, sehingga dapat merangsang industri kreatif dilingkungan sekitar. Joglo dan Gamelan berperan sebagai daya tarik untuk meningkatkan kunjungan masyarakat luar ke desa Jetis lokasi Joglo itu berada. Dampak dari kunjungan diharapkan mampu semakin 
melibatkan partisipasi warga desa dan mampu terlibat sebagai penyedia sarana pelengkap kepariwisataan dan sarana penunjang kepariwisataan.

\section{SIMPULAN}

Potensi pariwisata budaya perlu digalakkan dengan melibatkan warga desa, dengan dukungan website dan video sebagai langkah awal mempromosikan keberadaan Joglo. Era digital informasi dan mudahnya akses informasi, keberadaan Joglo akan mudah dipromosikan melalui website, media sosial, YouTube. Pendampingan terhadap warga perlu dilakukan berkala meski program pengabdian sudah berakhir. Pengelolaan website harus terus dijalankan sehingga mampu melanjutkan penambahan jumlah konten-konten terbaru aktivitas kebudayaan di Joglo.

\section{REFERENSI}

Herington, N., Elford, D. P., Swallowe, G. M., Chalmers, L., Perrin, R., \& Moore, T. R. (2010). Normal modes of a Gamelan Gong. In 1st EAA Euroregio. Congress on Sound and Vibration, Ljulbjana, Slovenia, 15th-18th September 2010 (pp. 1942-1950). Ljulbjana: European Acoustics Association, Slovenian Acoustical Society, and Alps Adria Acoustics Association.

Maulana, Y. (2017). Menpar: Industri pariwisata kultural potensi terbesar. Retrieved December 16, 2018 from https://swa.co.id/wicf/news/menpar-industri-pariwisata-kulturalpotensi-terbesar

Priyanto, \& Safitri, D. (2016). Pengembangan potensi desa wisata berbasis budaya tinjauan terhadap desa wisata di jawa tengah. Jurnal Vokasi Indonesia, 4(1), 76-84.

Purwati, P. (2016). Fenomena selfie kalangan remaja perempuan di instagram. Interaksi Online, 13(1), 1-12.

Raharjo, E. (2017). Dana keistimewaan DIY tahun 2018 meningkat jadi Rp 1 T. Retrieved December 16, 2018 from https://news.detik.com/berita-jawa-tengah/d-3768510/danakeistimewaan-diy-tahun-2018-meningkat-jadi-rp-1-t

Riyanta, A. (2018). Yogyakarta, Destinasi pariwisata kelas dunia. Retrieved December 16, 2018 from https://www.radarjogja.co.id/2018/03/28/yogyakarta-destinasi-pariwisatakelas-dunia/

Subiyantoro, S. (2011). Rumah tradisional joglo dalam estetika tradisi jawa. Bahasa dan Seni: Jurnal Bahasa, Sastra, Seni, dan Pengajarannya, 39(1), 68-78.

Sudarmadi, T. (2018). Pengembangan potensi kepariwisataan berbasis masyarakat di Desa Pengkol, Kabupaten Sukoharjo, Jawa Tengah. Bakti Budaya, 1(1), 73-91.

Widyawati, C. (2018). Peranan partisipasi masyarakat lokal dalam pengembangan wisata heritage di Trowulan. Jurnal Pariwisata, 5(2), 83-94. 